\title{
Quality assurance of diatom counts in Europe: towards harmonized datasets
}

\author{
Maria Kahlert 1,* \\ Phone 0046(0)18-673145 \\ Emailmaria.kahlert@slu.se \\ Éva Ács 2 \\ Salome F. P. Almeida 3 \\ Saúl Blanco 4,5 \\ Mirko Dreßler 6 \\ Luc Ector 7 \\ Satu Maaria Karjalainen \\ Antonia Liess 1 \\ Adrienne Mertens 9 \\ Jako van der Wal 10 \\ Sirje Vilbaste 11
}


Petra Werner 12

1 Department of Aquatic Sciences and Assessment, Swedish University of Agricultural Sciences, P. O. Box 7050, 75007 Uppsala, Sweden

2 Danube Research Institute, MTA Centre for Ecological Research, Karolina út 29, Budapest, 1113 Hungary

3 Biology Department and GeoBioTec Research Centre, University of Aveiro, 3810-193 Aveiro, Portugal

4 Department of Biodiversity and Environmental Management, University of León, 24071 León, Spain

5 Present Address: The Institute of the Environment, La Serna, 58, 24007 León, Spain

6 Department for Botany and Botanical Garden, Institute of Bio-Science, University of Rostock, Wismarsche Str. 8, 18057 Rostock, Germany

7 Environmental Research and Innovation Department (ERIN), Luxembourg Institute of Science and Technology (LIST), 41 rue du Brill, 4422 Belvaux, Luxembourg

8 Finnish Environment Institute, University of Oulu, P. O. Box 413, 90014 Oulu, Finland

9 Grontmij Nederland B.V., P. O. Box 95125, 1090 HC Amsterdam, The Netherlands

10 AQUON, Korte Huifakkerstraat 6, 4815 PS Breda, The Netherlands

11 Centre for Limnology, Estonian University of Life Sciences, Kreutzwaldi 5D, 51014 Tartu, Estonia 
12 Diatoms as Bioindicators, Grainauer Str. 8, 10777 Berlin, Germany

\begin{abstract}
Investigations on organism ecology, biodiversity and biogeography often use large compiled datasets to extract information on species ecological preferences, which then can be used in environmental assessment. Freshwater benthic diatoms are commonly used in this context. However, it is important that the taxonomic information of the separate diatom datasets is compatible. At present, inconsistencies between diatom datasets, mainly due to differences and uncertainties in diatom identification, may misinform diatom taxon-specific ecological preferences, geographical distribution and water quality assessment. It is our opinion that these inconsistencies in diatom datasets can be reduced with quality assurance (QA), such as identification exercises. However, the results of these exercises must be well documented and well communicated; otherwise, gained knowledge may not spread inter-regionally or internationally. As a first step to reach greater consistency in QA/harmonization studies, this article (1) presents and compares information of existing diatom identification and counting QA from published and grey (non-peer reviewed) European literature to identify advantages and drawbacks of each approach; (2) summarizes taxa that can easily be misidentified according to European identification exercises; and (3) suggests a consistent design of identification exercises for diatom dataset QA.

AQ1
\end{abstract}

\title{
Keywords
}

Bioindicator

Identification exercise

Intercalibration 
Inter-laboratory comparison

Ring test

European Water Framework Directive

Handling editor: Sonja Stendera

\section{Introduction}

Diatoms are increasingly used for freshwater environmental assessment world-wide (Stevenson et al., 2010; Stevenson \& Smol, 2015 ). Thus, a lot of information is gathered that could be used for new studies of diatom ecological traits, diatom biodiversity patterns and diatom biogeography. However, this is only possible if datasets can be merged easily. Even though diatom indices have been proven to be quite robust for the assessment of ecological status (Kelly et al., 2009; Kahlert et al., 2012; Kelly \& Ector, 2012; Almeida et al., 2014), diatom taxa lists can often not be compared directly. The reason for this is the lack of harmonization of diatom identification and counting techniques among regions or countries, which leads to inconsistent diatom datasets if not a form of taxa harmonization is used before analysis (Vyverman et al., 2007; Stevenson et al., 2010; Kelly et al., 2014). Thus, to prevent dataset inconsistencies, some form of standardized quality assurance (QA) is imperative (Kahlert et al., 2009; Dreßler et al., 2014).

QA is a way of systematically comparing results (here diatom taxonomic composition data, further called diatom counts or diatom datasets) to a standard, with an integrated monitoring of the involved processes and an associated feedback loop. QA may be a part of quality control but should not be mistaken for it. QA aims at error prevention, whereas quality control focuses on the control of the final results. To improve consistency between diatom datasets from different laboratories, QA of taxonomic methods should be broad, including identification exercises, workshops, regular internal training and education programs (Kelly, 2013). QA may even include diatom sample 
auditing by accredited diatom taxonomists or photographic taxa documentation (Kelly, 2013; pers. comm. Mertens, Werner). In general, QA should help to first identify and then prevent error sources, such as environmental variability, workforce variability (e.g. in training or adherence to methodology), technical errors and equipment failure (specified in ISO/IEC, 2005).

Inconsistencies in diatom counts have many sources. However, taxon identification uncertainties often contribute mueh more to overall inconsistency between datasets than other error sources (Kelly, 1997; Prygiel et al., 2002; Alverson et al., 2003; Van der Molen \& Verdonschot, 2004; Lavoie et al., 2005; Besse-Lototskaya et al., 2006; Kahlert et al., 2009). Even though all uncertainty sources should be minimized as much as possible, we think that agreement on consistent diatom identification will be the greatest challenge in the dataset harmonization. Diatom identification exercises are very demanding, because there are over a thousand freshwater diatom taxa in Europe (Guiry \& Guiry, 2015), and diatom taxonomy is developing fast (Medlin \& Kaczmarska, 2004; Mann, 2010; Mann \& Vanormelingen, 2013; Zimmermann et al., 2014). Therefore, we consider it particularly important to spread and exchange knowledge about best practice of diatom taxonomic identification exercises.

Different countries designate identification exercises in many ways. Some of the terms used are ring test, harmonization exercise, intercalibration, proficiency testing and intercomparison. A ring test defines the process of a reference institute which sends replicate samples to the participants to be analysed, and the results reported within a given time frame. Then, the reference institute statistically analyses, evaluates and interprets the results. The term harmonization exercise emphasizes the need of taxonomic consensus between laboratories and countries (e.g. Kahlert et al., 2009). Intercalibration is the process that ensures that several laboratories produce compatible data (Taylor, 1987). The term proficiency testing highlights the fact that the skills are actually tested in a type of exam. Finally, intercomparison means the mutual comparison of laboratories and is often used as synonym to proficiency testing. A diatom identification exercise might combine two or more features of the above mentioned terms. In any type of diatom identification exercise, diatom samples are analysed in the home laboratory according 
to the established routines, and the results of the diatom counts are then sent for central evaluation. Often, but not always, the exercise is followed by a workshop where the participants discuss the results of the exercise.

In Europe, diatom counting and their QA are an essential part of implementing the European Water Framework Directive (The European Parliament and the Council of the European Union, 2000). However, the existing European Committee for Standardization (CEN, 2012) provides only general guidance for the design of QA and does not specifically mention diatom count QA. Consequently, each European member state has developed different national or regional QA measures for diatom counts, complicating comparisons and information exchange. In addition, European QA measures are often only published in grey (non-peer reviewed) literature and often not in English.

This paper provides critical information for diatom researchers and managers to reach greater consistency in QA/harmonization studies. First, we present and compare information on the implementation of diatom count QA in Europe, to identify advantages and drawbacks of each approach. Second, we summarize problematic groups of taxa, highlighted by European identification exercises. And third, based on the above, we suggest a design for diatom identification exercises in order to provide consistent diatom count QA.

\section{Overview and comparison of diatom count QA in Europe}

Information on diatom count QA was collected in two steps. First, all European countries were asked to answer a questionnaire focusing on diatom identification exercises (in 2012, with an update in 2014) and we received 16 answers, which are summarized in Table 1 . Second, additional information was extracted from grey literature (listed in Table 2) and personal communications.

\section{Table 1}

European quality assurance (QA) and quality control measures for diatom counts used in bio-monitoring 


\begin{tabular}{|c|c|c|c|c|c|c|c|c|}
\hline Country & $\begin{array}{l}\text { Sample } \\
\text { origin }\end{array}$ & $\begin{array}{l}\text { No. } \\
\text { samples }\end{array}$ & $\begin{array}{l}\text { Diatom } \\
\text { analysts }\end{array}$ & Exercises & Frequency & Organizer & $\begin{array}{l}\text { No. of } \\
\text { participants }\end{array}$ & Sampling \\
\hline Austria & $\mathrm{NM}$ & $>200$ & $\mathrm{C}$ & $\mathrm{y}$ & $\begin{array}{l}\text { Every } \\
3 \text { years }\end{array}$ & $\mathrm{A}$ & $5-6$ & $\mathrm{n}$ \\
\hline Belgium-Flanders & $\begin{array}{l}\text { NM, } \\
\text { RM }\end{array}$ & 380 & $\mathrm{~A}, \mathrm{R}, \mathrm{C}$ & $\mathrm{n}^{\mathrm{b}}$ & & $\mathrm{A}^{\mathrm{b}}$ & & \\
\hline Belgium-Wallonia & NM & 150 & $\mathrm{~A}, \mathrm{C}$ & $\mathrm{y}$ & Annually & A & & \\
\hline Czech Republic & $\mathrm{NM}$ & $>360$ & $A, R$ & $\mathrm{n}$ & & & & \\
\hline France & $\mathrm{NM}$ & $\sim 2000$ & $\mathrm{~A}, \mathrm{C}, \mathrm{R}$ & $\mathrm{y}^{\mathrm{c}}$ & Annually & $\mathrm{A}, \mathrm{R}$ & $15-25$ & $\mathrm{y}$ \\
\hline Germany & $\begin{array}{l}\text { NM, } \\
\text { RM }\end{array}$ & $>1000$ & $\mathrm{~A}, \mathrm{C}, \mathrm{R}$ & $\mathrm{y}$ & Biannually & $A, R$ & $30-40$ & $\mathrm{n}$ \\
\hline Hungary & $\begin{array}{l}\text { NM, } \\
\text { RM }\end{array}$ & $\sim 500$ & $\mathrm{~A}, \mathrm{R}$ & $\mathrm{y}$ & $\begin{array}{l}\text { Every } \\
4 \text { years }\end{array}$ & $\mathrm{C}$ & 7 & $\mathrm{n}$ \\
\hline Ireland & $\begin{array}{l}\text { NM, } \\
\text { RM }\end{array}$ & 250 & $\mathrm{~A}$ & $-^{\mathrm{e}}$ & Annually & & & \\
\hline Italy & $\begin{array}{l}\text { NM, } \\
\text { RM }\end{array}$ & $>800$ & $\mathrm{~A}, \mathrm{R}$ & $y^{f}$ & Occasionally & $\mathrm{A}$ & 32 & $\mathrm{n}$ \\
\hline Netherlands ${ }^{\mathrm{g}}$ & $\begin{array}{l}\text { NM, } \\
\text { RM }\end{array}$ & 900 & $\mathrm{~A}, \mathrm{C}, \mathrm{R}$ & $\mathrm{y}$ & Annually ${ }^{\mathrm{h}}$ & A & $5-10$ & $\mathrm{n}$ \\
\hline NorBAF & & & & $\mathrm{y}$ & Biannually & $\mathrm{C}, \mathrm{R}$ & $15-20$ & $\mathrm{n}$ \\
\hline Estonia & $\mathrm{NM}$ & 100 & $\mathrm{R}$ & NorBAF $^{\mathrm{j}}$ & & & & \\
\hline Finland & $\begin{array}{l}\text { NM, } \\
\text { RM }\end{array}$ & $>400$ & $\mathrm{C}, \mathrm{R}$ & NorBAF & & & & \\
\hline Sweden & & $\sim 200$ & $\mathrm{C}, \mathrm{R}$ & NorBAF & & & & \\
\hline
\end{tabular}




\begin{tabular}{|c|c|c|c|c|c|c|c|c|}
\hline Country & $\begin{array}{l}\text { Sample } \\
\text { origin }\end{array}$ & $\begin{array}{l}\text { No. } \\
\text { samples }\end{array}$ & $\begin{array}{l}\text { Diatom } \\
\text { analysts }\end{array}$ & Exercises & Frequency & Organizer & $\begin{array}{l}\text { No. of } \\
\text { participants }\end{array}$ & Sampling \\
\hline & $\begin{array}{l}\text { NM, } \\
\text { RM }\end{array}$ & & & & & & & \\
\hline Spain & $\begin{array}{l}\text { NM, } \\
\text { RM }\end{array}$ & $>1000$ & $\mathrm{C}, \mathrm{R}$ & $\mathrm{n}$ & & & & \\
\hline Portugal & $\mathrm{RM}$ & $\sim 400^{\mathrm{k}}$ & $\mathrm{A}, \mathrm{C}, \mathrm{R}$ & $\mathrm{n}$ & & & & \\
\hline UK & $\begin{array}{l}\mathrm{NM} \\
\mathrm{RM}\end{array}$ & $>1000$ & $\mathrm{~A}, \mathrm{C}$ & $\mathrm{y}$ & Annually ${ }^{1}$ & $\mathrm{C}$ & $50-60$ & $\mathrm{n}$ \\
\hline Country & $\begin{array}{l}\text { Slide } \\
\text { prep. }\end{array}$ & Counting & $\begin{array}{l}\text { No. of } \\
\text { count }\end{array}$ & Workshop & Cert. & Report & Fee & Thresh. \\
\hline Austria & $\mathrm{n}$ & $\mathrm{y}$ & $5-7$ & $\mathrm{y}$ & $\mathrm{n}$ & $-^{\mathrm{a}}$ & Free & $\mathrm{y}$ \\
\hline Belgium-Flanders & & & & & & & & $\mathrm{n}$ \\
\hline Belgium-Wallonia & & $\mathrm{y}$ & & $\mathrm{y}$ & & & & $\mathrm{y}$ \\
\hline Czech Republic & & & & & & & & $\mathrm{n}$ \\
\hline France & $\mathrm{y}$ & $\mathrm{y}$ & $1-4$ & $\mathrm{y}$ & $\mathrm{n}$ & $\mathrm{y}$ & Free & $\mathrm{y}$ \\
\hline Germany & $\mathrm{n}$ & $\mathrm{y}$ & $2-4$ & $\mathrm{y}$ & $\mathrm{y}$ & $\mathrm{y}^{\mathrm{d}}$ & $300 €$ & $\mathrm{y}$ \\
\hline Hungary & $\mathrm{y}$ & $\mathrm{y}$ & 2 & $\mathrm{y}$ & $\mathrm{y}$ & $\mathrm{y}$ & $150 €$ & $\mathrm{y}$ \\
\hline Ireland & & & & & & & & $\mathrm{n}$ \\
\hline Italy & $\mathrm{n}$ & $\mathrm{y}$ & 1 & $\mathrm{y}$ & $\mathrm{y}$ & $\mathrm{y}$ & Free & $\mathrm{y}$ \\
\hline Netherlands ${ }^{\mathrm{g}}$ & $\mathrm{y}$ & $\mathrm{y}$ & 1 & $\mathrm{n}^{\mathrm{i}}$ & $\mathrm{n}$ & $\mathrm{y}$ & $550 €$ & $\mathrm{y}$ \\
\hline NorBAF & $\mathrm{y}$ & $\mathrm{y}$ & $2-5$ & $\mathrm{y}$ & $\mathrm{y}$ & $y^{d}$ & $300 €$ & $\mathrm{y}$ \\
\hline
\end{tabular}




\begin{tabular}{|c|c|c|c|c|c|c|c|c|}
\hline Country & $\begin{array}{l}\text { Sample } \\
\text { origin }\end{array}$ & $\begin{array}{l}\text { No. } \\
\text { samples }\end{array}$ & $\begin{array}{l}\text { Diatom } \\
\text { analysts }\end{array}$ & Exercises & Frequency & Organizer & $\begin{array}{l}\text { No. of } \\
\text { participants }\end{array}$ & Sampling \\
\hline \multicolumn{9}{|l|}{ Estonia } \\
\hline \multicolumn{9}{|l|}{ Finland } \\
\hline \multicolumn{9}{|l|}{ Sweden } \\
\hline Spain & & & & & & & & $\mathrm{n}$ \\
\hline Portugal & & & & & & & & $\mathrm{n}$ \\
\hline UK & $\mathrm{n}$ & $\mathrm{y}$ & 5 & $\mathrm{n}^{\mathrm{m}}$ & $\mathrm{n}$ & $\mathrm{y}$ & $£ 300$ & $y^{\mathrm{n}}$ \\
\hline
\end{tabular}

The columns represent the following information about diatom sample counting and diatom identification exercises for each $c c$ Sample origin indicates if the diatom samples are counted in national (NM) and/or regional monitoring programs (RM). Sampl. indicates how many samples are being counted per year in the monitoring programs. Diatom analyst indicates who counts the samples, authorities (A), consultants (C) or researchers (R). Exercise indicates whether ring tests or similar tests are performed frequency indicates how often these are conducted and organizer by whom they are organized, by authorities (A), consultants ( researchers (R). Participant no. indicates how many diatom analysts attend the exercise. Sampling and slide preparation yes (y (n) represents whether diatom sampling and permanent slide preparation are a part of the exercise. Counting, yes (y) or no (n) indicates whether diatom samples are counted according to a standard protocol. Counted no. represents the number of samples counted by each participant. Workshop and certificate (Cert.) yes (y) or no (n) indicates if a workshop was held and if certifica were given. Report represents if the exercise was followed up with a written report. Fee shows the costs of participation in the exercise. Threshold (Thresh.) indicates whether a quality protocol was part of the exercise, i.e. a diatom analyst had to pass a threshold of correctly identified taxa. Auditors yes (y) or no (n) indicates whether there were auditors in the ring test. NorBAF: Nordic-Baltic Network for Benthic Algae in Freshwater (they organize diatom joint identification exercises open for all Nordic countries)

${ }^{a}$ Internal information, not published

${ }^{b}$ Flanders Government is planning to organize a ring test in future. Some analysts from Flanders join ring tests in other (neighb countries

${ }^{\mathrm{c}}$ Annual ring tests for regional authorities. In a near future, those ring tests will also concern consultants

${ }^{\mathrm{d}}$ Sometimes scientific articles 


\begin{tabular}{|c|c|c|c|c|c|c|c|c|}
\hline Country & $\begin{array}{l}\text { Sample } \\
\text { origin }\end{array}$ & $\begin{array}{l}\text { No. } \\
\text { samples }\end{array}$ & $\begin{array}{l}\text { Diatom } \\
\text { analysts }\end{array}$ & Exercises & Frequency & Organizer & $\begin{array}{l}\text { No. of } \\
\text { participants }\end{array}$ & Sampling \\
\hline
\end{tabular}

${ }^{\mathrm{e}}$ Analysts from Ireland join the UK/Ireland ring test, and other international exercises

fIn 2011, a national intercalibration process among agencies through ISS (Superior Institute of Sanity) ISPRA circuit, about the counting and application of the protocol intercalibration common metric index (ICMi) took place

'Two different exercises are organized. The official one (RWS Water) is shown in table. The exercises of the NVKD (The Dut Flemish Society of Diatomists) are organized more irregularly

${ }^{\mathrm{h}}$ Changed to biannually (2012)

${ }^{\mathrm{i}}$ Organized since 2012

${ }^{j}$ Participating also in other international exercises

${ }^{\mathrm{k}}$ This preview was based on the number of available monitoring sites defined during the implementation of the WFD by the nat water Institute

${ }^{1}$ Five slides per year spread over the year, roughly every 2 months

${ }^{\mathrm{m}}$ But there is a parallel series of training workshops which often dovetail with the ring tests

${ }^{\mathrm{n}}$ The ring test is part of a broader accreditation scheme for Agency staff

"A pool of six "experts" and nine "mentors"

\section{Table 2}

Publicly available references of various intercalibration exercises in Europe

Kelly, M. G., 2013a. Freshwater Diatoms of Britain and Ireland. Ring test/intercalibration scheme. Slide 28: River Ehen, downstream from Ennerdale Water. Bowburn Consultancy, $11 \mathrm{pp}$.

United Kingdom
(UK)/Ireland 
Kelly, M. G., 2013b. Freshwater Diatoms of Britain and Ireland. Ring test/intercalibration scheme. Slide 29. Bowburn Consultancy, $11 \mathrm{pp}$.

Kelly, M. G., 2014. Freshwater Diatoms of Britain and Ireland. Ring test/intercalibration scheme. Slide 31: Bradgate Brook, Newton Linford, Leicestershire. Bowburn Consultancy, $11 \mathrm{pp}$.

Kelly, M. G. \& I. Jüttner, 2014a. Freshwater Diatoms of Britain and Ireland. Ring test/intercalibration scheme. Slide 32: River Derwent, Ebchester, County Durham. Bowburn Consultancy, $14 \mathrm{pp}$.

Kelly, M. G. \& I. Jüttner, 2014b. Freshwater Diatoms of Britain and Ireland. Ring test/intercalibration scheme. Slide 33: River Team, downstream of East Tanfield STW, County

Durham. Bowburn Consultancy, $12 \mathrm{pp}$.

Kelly, M. G. \& L. King, 2015. Freshwater Diatoms of Britain and Ireland. Ring

test/intercalibration scheme. Slide 36: Trillick Tributary, Carran Bridge, County Tyrone,

Northern Ireland. Bowburn Consultancy, $12 \mathrm{pp}$.

Kelly, M. G., I. Jüttner \& L. King, 2015. Freshwater Diatoms of Britain and Ireland. Ring test/intercalibration scheme. Slide 37: Semer Water, north Yorkshire. Bowburn Consultancy, $15 \mathrm{pp}$.

Kouwets, F. \& A. Veen, 2006. Rijkswaterstaat RIZA, Laboratorium-evaluerend onderzoek project 347. Rijkswaterstaat RIZApp.

Kouwets, F. \& A. Veen, 2007. Rijkswaterstaat RIZA, Laboratorium-evaluerend onderzoek project 377. Rijkswaterstaat RIZApp.

Kouwets, F. \& A. Veen, 2008. Rijkswaterstaat RIZA, Laboratorium-evaluerend onderzoek project 399. Rijkswaterstaat RIZApp.

Kouwets, F. A. C., 2012a. Rijkswaterstaat Waterdienst, Laboratorium-evaluerend onderzoek

RO550 benthische diatomeeën. Rijkswaterstaat Waterdienstpp.

Kouwets, F. A. C., 2012b. Rijkswaterstaat Waterdienst, Laboratory-evaluating ring-test Project

526. Rijkswaterstaat Waterdienstpp.

NVKD, 2015. The Dutch-Flemish Society of Diatomists (NVKD). http://www.diatom.nl/,

Accessed 2 March 2015.

Van de Vijver, B., 2013. Analyse van de resultaten van de Ringtest-2013. Diatomededelingen 37: 57-68.

Van de Vijver, B. \& H. Van Dam, 2010. Analyse van de Naardermeer ringtest resultaten.

Diatomededelingen 34: 21-34.

Ács, É. \& C. Bélavári, 2012. Jártassági vizsgálatok. Fitobenton. Vizsgálati minták eredményeinek értékelése. 2012. Évi zárójelentés. Budapest, 23 pp.

Hungary (HU)

Kahlert, M. \& R.-L. Albert, 2005. NorBAF - The Nordic-Baltic Network for Benthic Algae in Freshwater. www.norbaf.net, Accessed 17 March. 
Kahlert, M., R.-L. Albert, E.-L. Anttila, R. Bengtsson, C. Bigler, T. Eskola, V. Gälman, S. Gottschalk, E. Herlitz, A. Jarlman, J. Kasperoviciene, M. Kokociński, H. Luup, J. Miettinen, I. Paunksnyte, K. Piirsoo, I. Quintana, J. Raunio, B. Sandell, H. Simola, I. Sundberg, S. Vilbaste \& J. Weckström, 2009. Harmonization is more important than experience-results of the first Nordic-Baltic diatom intercalibration exercise 2007 (stream monitoring). Journal of Applied Phycology 21: 471-482.

Dreßler, M., P. Werner, S. Adler, M. Kahlert, G. Verweij, A. Schwarz, J. van der Wal, S. Kistenich, T. Hübener, A. Fazzone \& M. Galbiati, 2014. First German Benthic Diatom Intercalibration Exercise 2011/2012. Universität Rostock, Rostock, 203 pp.

Dreßler, M., G. Verweij, S. Kistenich, M. Kahlert \& P. Werner, 2015. Applied use of taxonomy: lessons learned from the first German intercalibration exercise for benthic diatoms. Acta Botanica Croatica 74: 211-232.

Werner, P., S. Adler \& M. Dreßler (in press): Effects of counting variances on water quality assessments: implications from four benthic diatom samples, each counted by 40 diatomists. Journal of Applied Phycology. doi: 10.1007/s10811-015-0760-9

Prygiel, J., P. Carpentier, S. Almeida, M. Coste, J.-C. Druart, L. Ector, D. Guillard, M.-A. Honoré, R. Iserentant, P. Ledeganck, C. Lalanne-Cassou, C. Lesniak, I. Mercier, P. Moncaut, M. Nazart, N. Nouchet, F. Peres, V. Peeters, F. Rimet, A. Rumeau, S. Sabater, F. Straub, M. Torrisi, L. Tudesque, B. Van de Vijver, H. Vidal, J. Vizinet \& N. Zydek, 2002. Determination of the biological diatom index (IBD NF T 90-354): results of an intercomparison exercise. Journal of Applied Phycology 14: 27-39.

Pers. comm. Luc Ector

Martone, C., S. Balzamo, S. Barbizzi, M. Belli, C. Vendetti, C. Puccinelli, S. Marcheggiani \& L. Mancini, 2012. Interconfronto sull'identificazione tassonomica delle diatomee bentoniche delle acque superficiali e sull'applicazione del Metodo ICMi (Intercalibration Common Metric Index). Rapporti 157/2012. ISPRA - Istituto Superiore per la Protezione e la Ricerca Ambientale, Roma, 34 pp.

Torrisi, M, C. Monauni, R. Zorza, V. Della Bella, M. Siligardi, C.E. Wetzel \& L. Ector, 2014. Ring-test su identificazione e protocollo di conteggio di diatomee bentoniche svolto all’Agenzia Provinciale per la Protezione dell'Ambiente di Trento (APPA). Biologia Ambientale 28: 113-127.

Torrisi, M., V. Della Bella, C. Monauni, R. Zorza, C.E. Wetzel, D. Hlúbiková, R. Dell'Anna \& L. Ector, 2015 - A ring-test to improve the correct use of diatoms to evaluate a water body strongly affected by urban waste water and pesticides. Case study Ribosc River (Trento, Italy). 9th Use of Algae for Monitoring RIvers and comparable habitats (UAMRIch, June 15th -17th 2015) and International Workshop on Benthic Algae Taxonomy (InBAT, June 17th-19th
Baltic Network for Benthic Algae in

Freshwater; NorBAF)

Germany (GER)

France (FR)

Italy (I) 
Mauthner-Weber, 2001-2012. Qualitätssicherung Biologie - Nationales Monitoring - Biologie (WGEV, GZÜV) von 2001 bis 2012; Phytobenthos. Wien, 47 pp.

Escudero, J. O., P. T. Giménez \& R. M. Ferreiro, 2008. Plan de calidad de los datos de los muestreos en ríos de la cuenca del Ebro: Análisis de la repetibilidad de las muestras biológicas. Laboratorio de Ensayos Técnicos S.A. (ENSAYA) \& Universidad de Navarra, Cuarte de Huerva (Zaragoza) \& Pamplona (Navarra), Confederación Hidrográfica del Ebro, 63 pp.

Diatom counts in Europe are conducted on many different administrative levels, from local authorities to regional and national monitoring institutes in each country, but also for research projects, by water authorities, research institutions or universities. These counts are done by a mixture of people including staff at central or regional water authorities, consultants, researchers and graduate students. Generally, the number of counts for routine monitoring range from approximately a hundred samples per year in Estonia to "several thousand" samples per year in the UK, Germany, France and Spain. Consequently, the European countries have different needs for diatom QA: a country with several large monitoring programs conducted at different administrative levels or a setup of analysts with varying degrees of expertise and experience will have a more urgent need for diatom QA than a country where a small number of samples is processed by a single analyst under the administration of a single authority.

As all countries strive for diatom count QA, the most countries participate in identification exercises as a part of QA. Many countries conduct their own national identification exercises, but small countries with few experts usually participate in neighbouring countries' identification exercises. These exercises are organized by the water authorities or alternatively by the diatom analysts (consultants or researchers), or in combination. The advantages of the organization by a national authority are a long-term approach including basic funding and a good acceptance of the outcomes of the identification exercises. On the other hand, an organization of diatom count QA by diatom analysts (consultants or researchers) directly provides the necessary expertise on diatoms. Researchers 
usually ensure the inclusion of the newest taxonomical views and may provide advice on how to separate species under the light microscope, while consultants ensure that the view of environmental assessment requirements and practical questions are taken into account.

The efforts of the conducted identification exercises are quite different, varying in frequency, as well as work load and costs. The frequency ranges from annually over biannually to once every 3 or 4 years. An exception is the $\mathrm{UK} /$ Ireland test which is organized as a continuous procedure, sending one diatom slide to the participating laboratories approximately every second month. Some countries carry out infrequent exercises or have only carried out a single one so far. The work load for the participants might include sampling, often the preparation of permanent diatom slides and always their counting according to standard protocols, varying from one to seven slides on each occasion. In some countries (France, Italy and the Netherlands), the calculation of diatom indices is also included in the exercise. Sometimes very strict protocols with time constraints are followed (Italy). However, most often experts have no time constraints for sample counting, and they count these in their own laboratories according to given standard protocols. Results are then sent in for central evaluation. Participation fees ranges from free to $550 €$. There are costs for the organization of identification exercises, so in case of free participation, costs are covered by other sources, often by the organizing authorities. Obviously, a high effort guarantees an intensive training, and frequent exercises ensure that the analysts' knowledge is up to date. On the other hand, if the invested efforts are considered to be too high, there is a risk of non-participation due to lack of time and funding.

The number of participants in these exercises is 5-60, which again highlights the different approaches between countries. A high number of participants enable the training of many analysts at the same time. Furthermore, the participants' fees cover the costs of the identification exercise. However, high participant numbers also make organization more difficult. Additionally, if the results of the exercise are discussed in a workshop connected to the identification exercise, low participant numbers are preferred in order to enable valuable discussions. If 
harmonized solutions to taxonomic problems are the goal of such a workshop, low participant numbers are definitely necessary. A workshop is, however, not always a given part of the identification exercises. An identification exercise might only consist of a number of samples to be counted and the comparison of the results of the participating laboratories in a report. Still, when the initial comparison is followed by a workshop and agreements on how to handle difficult taxa are attained, between analyst variation can be reduced (Kahlert et al., 2009). Evaluations of NorBAF (Nordic-Baltic Network for Benthic Algae in Freshwater, including Sweden, Finland and the Baltic countries) also showed that the workshop was the most appreciated part of the intercalibration exercise, where results were eagerly discussed and clarifications could be made.

Most countries hand out certificates in connection with the identification exercises, reflecting the intention of the exercises. Diatom identification exercises can have the form of a stringent test with time restriction (Italy; Martone et al., 2012), of more informal meetings coupled to formal certificates after passing a minimal threshold of correctly identified taxa (like in the NorBAF exercise, Kahlert \& Albert, 2005), or focus on reflective learning instead of examinations (UK and Ireland; Kelly, 2013). Certificates may thus only confirm participation without information on performance, or they may be used to certify that a participant has met a quality criterion such as in the tests of NorBAF, Germany and Hungary. The threshold can be based on the similarity of the diatom taxa lists established by the auditor(s) in comparison to the participant. In Hungary, an additional threshold based on the diatom ecological index values is calculated and compared with the audit. In the UK/Ireland ring test, only the index value threshold represents the limit of acceptable variation, but as the focus is on learning, there are no certificates (Kelly, 2013). Obviously, the choice of the auditor or expert (or group of experts) is important. An agreement must be reached on diatom taxonomy to achieve harmonized results. Expert opinions on taxonomy often vary, thus it is a sensitive issue. UK/Ireland solved this issue by appointing some of their most experienced experts to take turns on the responsibility for different samples, and additionally several experts count one slide to get natural and expert variability, per slide. All countries that conduct identification exercises also produce different types of written reports of the outcomes. 
As diatom identification exercises are part of diatom count QA, it is commonly expected that a laboratory accredited for diatom analyses ensures the analyst's skills via participation in it (see for example, The Swedish Board for Accreditation and Conformity Assessment (Swedac), 2011), and the responsible water authority might require the use of accredited laboratories based on ISO-IEC17025 (ISO/IEC, 2005) for diatom counts in monitoring programs. However, we are lacking information on what exactly is required to achieve the accredited status of a diatom expert, partly because the accreditation rules for analysts are not well formulated and also not well communicated. Often, the accreditation rules and the eventual in-house inspections do focus on technical routines of the accredited laboratory. In contrast, the requirements for diatom identification and counting skills are seldom specified in the accreditation.

\section{Common quality problems and problematic taxa groups}

Common quality problems encountered during the diatom identification exercises in Europe include (1) mistaking one taxon for another due to insufficient use of given taxonomic details for identification, leading to differences in the final diatom list, and in water quality index calculations if those taxa have different ecological requirements (Austria [Mauthner-Weber, 2001-2012], GER, UK/Ireland, Table 2); (2) identification problems due to imprecise taxonomic literature, i.e. ambiguous species' descriptions and documentation in the current identification literature (FR, GER, NL, NorBAF, UK/Ireland, Table 2) or not using mandatory identification literature (GER, NL, NorBAF, Table 2); and (3) overlooking of small taxa (FR, GER, NL, NorBAF, UK/Ireland, Table 2).

Identification problems occurred within similar taxa complexes in all exercises, despite geographical differences (Table 3 ). Most of these taxonomic groups are also common or abundant in European waters, and thus, relevant for environmental assessment. Consequently, solutions must be found to ensure QA of these common taxa. For example, the identification of single taxa from the Achnanthidium minutissimum complex was problematic in most identification exercises (Table 3). Sweden uses ecomorphotypes based on valve width thereby avoiding the need 
to differentiate on a species or variety level (Kahlert et al., 2007, 2009), whereas other countries try to clarify existing taxa concepts of this complex (e.g. Dreßler et al., 2014). These different solutions for problematic taxa illustrate the necessity of information exchange in order to achieve compatible diatom taxa datasets among countries.

\section{Table 3}

Taxa identified as problematic in intercalibration exercises of various European countries from publicly available sources (Table 2)

\begin{tabular}{|l|l|}
\hline Taxonomically problematic diatom groups & Country \\
\hline Achnanthidium minutissimum complex & $\begin{array}{l}\text { FR, GER, I, NL, } \\
\text { NorBAF, } \\
\text { UK/Ireland }\end{array}$ \\
\hline Amphora (small species) & FR, GER \\
\hline Cocconeis placentula Ehrenberg aggregate and similar taxa & FR, GER \\
\hline Former Cymbella microcephala complex (now Encyonopsis) & FR, NL, GER \\
\hline Cymbella excisa Kützing and similar taxa & FR, I \\
\hline Encyonema silesiacum (Bleisch) D.G. Mann and similar taxa & GER, NL \\
\hline Encyonema species & UK/Ireland \\
\hline Eunotia rhomboidea Hustedt vs. E. incisa W. Gregory & NorBAF \\
\hline 'long' Fragilaria Synedra) (mainly Fragilaria capucina Desmazières and similar taxa) & FR, GER, NL, \\
\hline 'short' Fragilaria sensu lato (Fragilaria elliptica Schumann and similar taxa) & UK/Ireland \\
\hline
\end{tabular}




\section{Taxonomically problematic diatom groups}

'short' Fragilaria sensu lato (Pseudostaurosira (Fragilaria/Staurosira) brevistriata (Grunow in Van Heurck) D.M. Williams \& Round) and similar taxa

'short' Fragilaria sensu lato (Staurosirella leptostauron (Ehrenberg) D.M. Williams \& Round, Staurosirella pinnata complex.)

Gomphonema gracile Ehrenberg sensu lato (complex, NorBAF: including Gomphonema exilissimum/parvulum)

Gomphonema olivaceolacuum (Lange-Bertalot \& E. Reichardt) Lange-Bertalot \& E. Reichardt

Gomphonema pumilum complex

'small' Navicula sensu lato (several taxa, e.g. Eolimna minima (Grunow) Lange-Bertalot \& W. Schiller, Fistulifera saprophila (Lange-Bertalot \& Bonik) Lange-Bertalot, Mayamaea permitis (Hustedt) Bruder \& Medlin, Adlafia, and similar taxa)

'medium' Navicula taxa (Navicula cryptotenella Lange-Bertalot vs. N. cryptotenelloides LangeBertalot, $N$. cryptocephala complex, N. lundii E. Reichardt vs. $N$. veneta Kützing, $N$. reichardtiana Lange-Bertalot vs. N. caterva M.H. Hohn \& Hellerman)

Nitzschia taxa (among others the Nitzschia palea complex, N. capitellata Hustedt, N. perminuta (Grunow) Peragallo, Nitzschia dissipata complex)

Nitzschia fonticola (Grunow) Grunow in Van Heurck vs. N. lacuum Lange-Bertalot.

Nitzschia soratensis E. Morales \& M.L. Vis \& N. inconspicua Grunow

Planothidium, Encyonopsis, Halamphora, Brachysira

Stephanodiscus and Cyclotella species

Tabellaria flocculosa (Roth) Kützing

\section{Country}

GER, UK/Ireland

NL, UK/Ireland

FR, NL, NorBAF, UK/Ireland

GER

FR, GER, I, NL

FR, GER, HU, NL, UK/Ireland

FR, GER, I, NL, NorBAF

FR, HU, I, NL, NorBAF

FR, GER

FR, UK/Ireland

GER, NL

NL

NorBAF,

UK/Ireland 


\section{Suggestions on the design of identification exercises}

QA of diatom identification and counting, at least in some countries, is still in its infancy with little consensus on best practice across Europe. Especially countries with low or unclear qualification requirements for diatom analysts, risk employing the cheapest and thus likely the most unqualified one. This might lead to low quality of the resultant diatom dataset. Overall, we would like to recall that it has been suggested that laboratory quality control should make up 10-20\% of the effort spent on routine analyses (Cheeseman \& Wilson, 1978). In general, we see a need for national/regional identification exercises and for additional European-wide identification exercises, in combination with improved information flow (Table 4).

\section{Table 4}

Suggestions on design and performance of national or regional identification exercises for QA of diatom counts, and on European-wide identification exercises, based on best practice experiences

\begin{tabular}{|c|c|c|c|c|}
\hline & $\begin{array}{l}\text { National/Regional } \\
\text { identification } \\
\text { exercises for } Q A \text { of } \\
\text { diatom counts }\end{array}$ & Notes & $\begin{array}{l}\text { European-wide } \\
\text { identification } \\
\text { exercises for an } \mathrm{EU} \\
\text { network/exchange }\end{array}$ & Notes \\
\hline Aim & \multicolumn{2}{|c|}{$\begin{array}{l}\text { To ensure QA of diatom counts on } \\
\text { national/regional level. Focus on taxa } \\
\text { identification and quantifiable results } \\
\text { coupled to education and training }\end{array}$} & \multicolumn{2}{|c|}{$\begin{array}{l}\text { To ensure a communication of best practice and } \\
\text { in cases of shared international catchments or } \\
\text { projects a harmonization of national and } \\
\text { regional diatom identification }\end{array}$} \\
\hline Organization & $\begin{array}{l}\text { Authorities, } \\
\text { Consultants and } \\
\text { Researchers } \\
\text { combined }\end{array}$ & $\begin{array}{l}\text { All groups should } \\
\text { be involved in the } \\
\text { organization, } \\
\text { especially } \\
\text { authorities should } \\
\text { highlight their }\end{array}$ & $\begin{array}{l}\text { Organizers and/or } \\
\text { auditors of national } \\
\text { exercises }\end{array}$ & \\
\hline
\end{tabular}




\begin{tabular}{|c|c|c|c|c|}
\hline & $\begin{array}{l}\text { National/Regional } \\
\text { identification } \\
\text { exercises for QA of } \\
\text { diatom counts }\end{array}$ & Notes & $\begin{array}{l}\text { European-wide } \\
\text { identification } \\
\text { exercises for an EU } \\
\text { network/exchange }\end{array}$ & Notes \\
\hline & & $\begin{array}{l}\text { support of the } \\
\text { exercises }\end{array}$ & & \\
\hline Frequency & $\begin{array}{l}\text { Preferably once a } \\
\text { year, or } \\
\text { continuously }\end{array}$ & $\begin{array}{l}\text { Trade-off between } \\
\text { need for training } \\
\text { and manageability }\end{array}$ & Every 2nd year & $\begin{array}{l}\text { Coupled to a diatom } \\
\text { meeting/symposium }\end{array}$ \\
\hline $\begin{array}{l}\text { Target group of } \\
\text { participants }\end{array}$ & $\begin{array}{l}\text { Authorities, } \\
\text { consultants and } \\
\text { researchers }\end{array}$ & $\begin{array}{l}\text { Involved in } \\
\text { counting on } \\
\text { national/regional } \\
\text { level }\end{array}$ & $\begin{array}{l}\text { For participation, } \\
\text { organizers of the } \\
\text { national/regional } \\
\text { identification } \\
\text { exercises }\end{array}$ & $\begin{array}{l}\text { For communication of } \\
\text { results: everybody } \\
\text { counting diatoms. } \\
\text { Participants must be } \\
\text { diatom experts and } \\
\text { should also be familiar } \\
\text { with the use of diatoms } \\
\text { for routine monitoring }\end{array}$ \\
\hline Number of participants & $15-20$ & $\begin{array}{l}\text { Enabling workshop } \\
\text { discussions and } \\
\text { high-quality } \\
\text { education }\end{array}$ & $15-20$ & $\begin{array}{l}\text { Harmonized solutions } \\
\text { might need a restricted } \\
\text { participant number }\end{array}$ \\
\hline $\begin{array}{l}\text { Design-sampling/sample } \\
\text { preparation }\end{array}$ & Occasionally & $\begin{array}{l}\text { Ensures detection of } \\
\text { problems not } \\
\text { coupled to } \\
\text { identification }\end{array}$ & Occasionally & $\begin{array}{l}\text { Ensures the coupling to } \\
\text { routine counting for } \\
\text { monitoring }\end{array}$ \\
\hline Design-Sample count & Yes & $\begin{array}{l}\text { Focus on prepared } \\
\text { slides ensures focus } \\
\text { on identification } \\
\text { problems }\end{array}$ & Yes & $\begin{array}{l}\text { Focus should be on the } \\
\text { main problems identified } \\
\text { by the national/regional } \\
\text { organizers }\end{array}$ \\
\hline $\begin{array}{l}\text { Design-Workshop } \\
\text { ISDR International Society }\end{array}$ & $\begin{array}{l}\text { Yes } \\
\text { or Diatom Research }\end{array}$ & & Yes & \\
\hline
\end{tabular}




\begin{tabular}{|c|c|c|c|c|}
\hline & $\begin{array}{l}\text { National/Regional } \\
\text { identification } \\
\text { exercises for QA of } \\
\text { diatom counts }\end{array}$ & Notes & $\begin{array}{l}\text { European-wide } \\
\text { identification } \\
\text { exercises for an EU } \\
\text { network/exchange }\end{array}$ & Notes \\
\hline & & $\begin{array}{l}\text { Training and } \\
\text { discussion of } \\
\text { harmonized } \\
\text { solutions }\end{array}$ & & $\begin{array}{l}\text { Discussion of } \\
\text { harmonized solutions }\end{array}$ \\
\hline Number of samples & Preferably 2 & $\begin{array}{l}\text { Alternating } \\
\text { samples: differing } \\
\text { ecology, including } \\
\text { both common taxa } \\
\text { as well as recently } \\
\text { described }\end{array}$ & $\begin{array}{l}2 \text { or more after } \\
\text { agreement }\end{array}$ & \\
\hline Auditor(s) & Yes & Preferably several & No & $\begin{array}{l}\text { All participants are } \\
\text { experts }\end{array}$ \\
\hline Quantifiable results & Yes & $\begin{array}{l}\text { With QC of counts: } \\
\text { BC criterion of } 60 \% \\
\text { compared to the } \\
\text { auditor(s) (Kelly } \\
2001 \text { ) }\end{array}$ & Yes & No QC necessary \\
\hline $\begin{array}{l}\text { Certificates-for } \\
\text { participation }\end{array}$ & Yes & & Not necessary & \\
\hline Certificates — with QC & Yes & $\begin{array}{l}\text { Authorities need to } \\
\text { assess if diatom } \\
\text { counts by a certain } \\
\text { expert are } \\
\text { harmonized on } \\
\text { national/regional } \\
\text { level }\end{array}$ & Not necessary & \\
\hline
\end{tabular}




\begin{tabular}{|c|c|c|c|c|}
\hline & $\begin{array}{l}\text { National/Regional } \\
\text { identification } \\
\text { exercises for QA of } \\
\text { diatom counts }\end{array}$ & Notes & $\begin{array}{l}\text { European-wide } \\
\text { identification } \\
\text { exercises for an EU } \\
\text { network/exchange }\end{array}$ & Notes \\
\hline Fee & As low as possible & $\begin{array}{l}\text { Depending on } \\
\text { funding source, } \\
\text { but }>300 € \text { if funded } \\
\text { by fees only }\end{array}$ & None & \\
\hline $\begin{array}{l}\text { Communication of } \\
\text { results-report }\end{array}$ & $\begin{array}{l}\text { Yes, on } \\
\text { national/regional } \\
\text { level }\end{array}$ & $\begin{array}{l}\text { If possible with } \\
\text { translation to } \\
\text { English, or at least a } \\
\text { public digital } \\
\text { publication to } \\
\text { enable transfer of } \\
\text { knowledge. }\end{array}$ & $\begin{array}{l}\text { Not necessary, if } \\
\text { published on internet }\end{array}$ & $\begin{array}{l}\text { But scientific } \\
\text { publications possible and } \\
\text { desirable }\end{array}$ \\
\hline $\begin{array}{l}\text { Communication of } \\
\text { results - internet }\end{array}$ & $\begin{array}{l}\text { English WikiProject } \\
\text { linked to the ISDR }\end{array}$ & Fast publication & $\begin{array}{l}\text { English WikiProject } \\
\text { linked to the ISDR }\end{array}$ & Fast publication \\
\hline $\begin{array}{l}\text { Participant evaluation of } \\
\text { identification exercise }\end{array}$ & Yes & & Yes & \\
\hline
\end{tabular}

National or regional identification exercises aim to ensure QA of diatom counts on national/regional levels by addressing regional peculiarities and using the national language to ensure a good communication with the participating routine technicians (Table 4). The exercise should occasionally include sampling and sample preparation, but focus on taxa identification and quantifiable results coupled to a workshop for education and training (Table 4). A summary of the workshop outcome should be published in the national language. Ideally, the 
results should also be published in English on a common homepage. National/regional identification exercises should be organized by a combination of water authorities, researchers and consultants (Table 4).

National/regional identification exercises should occur once a year or continuously, with a fee as low as possible. To our experience, a number of 15-20 participants are the maximum to enable valuable discussions in a workshop. The target group would be the staff involved in diatom counting on a national/regional level including consultants, researchers and technicians (Table 4). When organized in a concentrated form (and not continuously), two samples per exercise have been shown feasible to keep the effort manageable. The content should vary reflecting different ecological settings, thus covering the broad spectrum of diatom taxa (Tables 3, 4). The use of several auditors or an expert panel is preferred over single auditors (Table 4), as then also eventual errors and problematic taxa groups can be agreed upon. Auditors should discuss inconsistent counting results openly and flexibly to harmonize their view of counting, prior to an analysis of participants' results.

Participant performance should be quantified and noted in a certificate (Table 4). For example, a Bray-Curtis similarity level of $>60 \%$ typically indicated good agreement of diatom counts between analyst and auditor in previous studies (Kelly, 2001, confirmed by GER, HU, NorBAF Table 2). Using this threshold, it is possible to decrease the index variation of analysts and auditors to the variation of replicate samples (Kahlert et al., 2009, and unpublished NorBAF report of 2011).

However, while national/regional identification exercises may reduce variation within a country (or region), they can, potentially, perpetuate systematic errors among countries and regions (Van de Vijver \& van Dam, 2010; Kahlert et al., 2012). We, therefore propose a European-wide communication of QA of diatom counts to inform about national and regional workshop results. An European-wide identification exercise would ensure an information flow among countries, enabling communication of best practice and harmonization of diatom data, which is particularly important for water bodies with international catchments or international projects or when 
investigating organism ecology, biodiversity and biogeography. We suggest a frequency for European tests of every second year, connected to a diatom meeting. This setup would enable the incorporation of the outcomes into regional identification exercises in the year in between and would keep the workload manageable (Table 4). European identification exercises and workshops should be held in English for communication reasons. We suggest the target group to be the coordinators or auditors of the national identification exercises to ensure costeffective workshops with constructive discussions. The outcomes of the European identification exercises should then be discussed in the regional and national workshops (Table 4).

Identification exercises at European level should include the practical counting of diatoms. Only then are relevant problems among participants discovered. The focus should be on the main problems identified by the national/regional identification exercises. Quantifiable results should also be included to enable the comparison of participant results.

A report summarizing the results is necessary for archiving and communication for both the national/regional and the European identification exercises. We suggest publishing the results also as a WikiProject (Wikipedia, 2015a) about "Diatom identification for applied use" linked to the website of the International Society for Diatom Research (ISDR). This publication form would ensure that not all the workload is on the organizers and would enable an active, open and democratic participation of diatomists, current updates and the sharing of practical solutions. A WikiProject would not depend on a single funding source or single authority; it would be curated by the established Wikipedia community and would thus hopefully be carried by many shoulders and long-living. We are not aiming at starting taxonomical sites for diatom species; such efforts are already under way (Maddison \& Schulz, 2007; Spaulding et al., 2010; Wikipedia, 2015a, b, c, d, e). Instead, we are thinking of webpages for diatomists working with identification for environmental assessment, where we would link to the national identification exercise reports and results, and create sites for the issues that cause the main problems in this field. Here, we would publish agreed solutions and conventions to handle difficult diatom groups (such as given in 
Table 3). For further improvement of all national and international tests, we additionally recommend routine evaluations of the identification exercises by the participants.

\section{Conclusions}

In summary, we believe that diatom count QA can and should be improved by reciprocal knowledge transfer between regions and countries. Furthermore, we think it is essential to clearly formulate the requirements and qualification necessary for an accredited diatomist. These qualifications should include a description of required diatom identification skills. We suggest regular participation in identification exercises as part of every diatom counting QA. We recommend performing national (or regional) identification exercises with a quantifiable outcome, a threshold to be attained and certificates issued. An identification exercise should be followed by a workshop where common problems are discussed and solved. We recommend furthermore Pan-European identification exercises to ensure communication of best practice, and in cases of international catchments or projects, a harmonization of regional and national diatom identification. We also recommend open discussions among all people involved in diatom counting to achieve taxa identification harmonization. Discussions should also include the ecology and potential indicator values of diatom taxa for monitoring purposes. Last, solutions and discussions should be made public as soon as possible, incorporated into a WikiProject linked to the ISDR for fast publication.

\section{Acknowledgments}

We thank everyone who was contacted for this analysis and helped to find information: Martyn Kelly (UK, Bowburn consultancy), Bryan Kennedy (IE, EPA), Libuse Opatrilova (CZ, T. G. Masaryk Water Research Institute), Frans Kouwets (NL, Rijkswaterstaat Water, Verkeer en Leefomgeving), Gaby Verhaegen (BE, Flanders, VMM), Christine Keulen (BE, Wallonia, Service Public de Wallonie), Juliette Rosebery (FR, Irstea grpt de Bordeaux UR EABX), Matteo Galbiati \& Andrea Fazzone (IT, ARPA Lombardia), Pepita Nolla (ES, PhytoLab 
Control) \& Elisabet Tornés (ES, ICRA) and Richild Mauthner-Weber (AU, Federal Ministry of Agriculture, Forestry, Environment and Water Management) (additionally to the authors). We also want to thank the organizers and participants of the diatom identification exercises who kindly provided the grey literature compiled in this study. We thank Martyn Kelly for a critical review of a first version of this manuscript, and Matteo Galbiati, Andrea Fazzone, Richild Mauthner-Weber, Juliette Rosebery, Elisabet Tornés and Gaby Verhaegen for their valuable contributions to it. We also thank the reviewers, who contributed considerably to the improvement of the manuscript.

\section{References}

Almeida, S. F. P., C. Elias, J. Ferreira, E. Tornés, C. Puccinelli, F. Delmas, G. Dörflinger, G. Urbanič, S. Marcheggiani, J. Rosebery, L. Mancini \& S. Sabater, 2014. Water quality assessment of rivers using diatom metrics across Mediterranean Europe: a methods intercalibration exercise. Science of the Total Environment 476-477: 768-776.

Alverson, A. J., K. M. Manoylov \& R. J. Stevenson, 2003. Laboratory sources of error for algal community attributes during sample preparation and counting. Journal of Applied Phycology 15: 357-369.

Besse-Lototskaya, A., P. F. M. Verdonschot \& J. A. Sinkeldam, 2006. Uncertainty in diatom assessment: sampling, identification and counting variation. Hydrobiologia 566: 247-260.

CEN, 2012. Water quality - Guidance standard on interlaboratory comparison studies for ecological assessment. EN 16101:2012. Comité Européen de Normalisation, Geneva. 
Cheeseman, R. V.\& A. L. Wilson, 1978. Manual on Analytical Quality Control for the Water Industry Water Research Centre Technical Report. vol 66, Medmenham

Dreßler, M., P. Werner, S. Adler, M. Kahlert, G. Verweij, A. Schwarz, J. van der Wal, S. Kistenich, T. Hübener, A. Fazzone \& M. Galbiati, 2014. First German Benthic Diatom Intercalibration Exercise 2011/2012. http://www.planktonforum.eu/index.php?id=8\&no_cache=1\&L=1. Accessed 27 Jan 2015.

Guiry, M. D. \& G. M. Guiry, 2015. AlgaeBase. World-wide electronic publication, National University of Ireland, Galway. http://www.algaebase.org. Accessed 27 Jan 2015

ISO/IEC, 2005. General requirements for the competence of testing and calibration laboratories. ISOIEC17025:2005. ISO Committee on conformity assessment (CASCO).

Kahlert, M. \& R.-L. Albert, 2005. NorBAF - The Nordic-Baltic Network for Benthic Algae in Freshwater. NorBAF - The Nordic-Baltic Network for Benthic Algae in Freshwater. www.norbaf.net, Accessed 17 March.

Kahlert, M., C. Andrén, \& A. Jarlman, 2007. Bakgrundsrapport för revideringen 2007 av bedömningsgrunder för Påväxt - kiselalger i vattendrag. 2007:23. Institutionen för miljöanalys, Swedish University of Agricultural Science, Uppsala, Sweden. [Available from:

http://publikationer.slu.se/Filer/bakgrundsrapport_kiselalger07_23.pdf].

Kahlert, M., R.-L. Albert, E.-L. Anttila, R. Bengtsson, C. Bigler, T. Eskola, V. Gälman, S. Gottschalk, E. Herlitz, A. Jarlman, J. Kasperoviciene, M. Kokociński, H. Luup, J. Miettinen, I. Paunksnyte, K. Piirsoo, I.

Quintana, J. Raunio, B. Sandell, H. Simola, I. Sundberg, S. Vilbaste \& J. Weckström, 2009. Harmonization is 
more important than experience-results of the first Nordic-Baltic diatom intercalibration exercise 2007 (stream monitoring). Journal of Applied Phycology 21: 471-482.

Kahlert, M., M. Kelly, R.-L. Albert, S. F. P. Almeida, T. Bešta, S. Blanco, M. Coste, L. Denys, L. Ector, M. Fránková, D. Hlúbiková, P. Ivanov, B. Kennedy, P. Marvan, A. Mertens, J. Miettinen, J. Picinska-

Falltynowicz, J. Rosebery, E. Tornés, S. Vilbaste \& A. Vogel, 2012. Identification versus counting protocols as sources of uncertainty in diatom-based ecological status assessments. Hydrobiologia 695: 109-124.

Kelly, M., 1997. Sources of counting error in estimations of the trophic diatom index. Diatom Research 12: 255 -262 .

Kelly, M. G., 2001. Use of similarity measures for quality control of benthic diatom samples. Water Research 35: 2784-2788.

Kelly, M., 2013. Building capacity for ecological assessment using diatoms in UK rivers. Journal of Ecology and Environment 36: 89-94.

Kelly, M. G. \& L. Ector, 2012. Effect of streamlining taxa lists on diatom-based indices: implications for intercalibrating ecological status. Hydrobiologia 695: 253-263.

Kelly, M., H. Bennion, A. Burgess, J. Ellis, S. Juggins, R. Guthrie, J. Jamieson, V. Adriaenssens \& M. Yallop, 2009. Uncertainty in ecological status assessments of lakes and rivers using diatoms. Hydrobiologia 633: 5-15.

Kelly, M., G. Urbanic, E. Acs, H. Bennion, V. Bertrin, A. Burgess, L. Denys, S. Gottschalk, M. Kahlert, S. M. Karjalainen, B. Kennedy, G. Kosi, A. Marchetto, S. Morin, J. Picinska-Fałtynowicz, S. Poikane, J. Rosebery, I. 
Schoenfelder, J. Schoenfelder \& G. Varbiro, 2014. Comparing aspirations: intercalibration of ecological status concepts across European lakes for littoral diatoms. Hydrobiologia 734: 125-141.

Lavoie, I., K. M. Somers, A. M. Paterson \& P. J. Dillon, 2005. Assessing scales of variability in benthic diatom community structure. Journal of Applied Phycology 17: 509-513.

Maddison, D. R. \& K.-S. Schulz, 2007. Tree of Life Web Project (ToL). http://tolweb.org/tree/. Accessed 2 Mar 2015.

Mann, D. G., 2010. Discovering diatom species: is a long history of disagreements about species-level taxonomy now at an end? Plant Ecology and Evolution 143: 251-264.

Mann, D. G. \& P. Vanormelingen, 2013. An inordinate fondness? The number, distributions, and origins of diatom species. Journal of Eukaryotic Microbiology 60: 414-420.

Martone, C., S. Balzamo, S. Barbizzi, M. Belli, C. Vendetti, C. Puccinelli, S. Marcheggiani \& L. Mancini, 2012. Interconfronto sull'identificazione tassonomica delle diatomee bentoniche delle acque superficiali e sull'applicazione del Metodo ICMi (Intercalibration Common Metric Index). Rapporti 157/2012. ISPRA Istituto Superiore per la Protezione e la Ricerca Ambientale, Roma.

Mauthner-Weber, 2001-2012. Qualitätssicherung Biologie - Nationales Monitoring - Biologie (WGEV, GZÜV) von 2001 bis 2012; Phytobenthos. Wien

Medlin, L. K. \& I. Kaczmarska, 2004. Evolution of the diatoms: V. Morphological and cytological support for the major clades and a taxonomic revision. Phycologia 43: 245-270. 
Prygiel, J., P. Carpentier, S. Almeida, M. Coste, J.-C. Druart, L. Ector, D. Guillard, M.-A. Honoré, R. Iserentant, P. Ledeganck, C. Lalanne-Cassou, C. Lesniak, I. Mercier, P. Moncaut, M. Nazart, N. Nouchet, F. Peres, V. Peeters, F. Rimet, A. Rumeau, S. Sabater, F. Straub, M. Torrisi, L. Tudesque, B. Van de Vijver, H. Vidal, J. Vizinet \& N. Zydek, 2002. Determination of the biological diatom index (IBD NF T 90-354): results of an intercomparison exercise. Journal of Applied Phycology 14: 27-39.

Spaulding, S. A., D. J. Lubinski \& M. Potapova, 2010. Diatoms of the United States. http://westerndiatoms.colorado.edu. Accessed 2 Mar 2015.

Stevenson, R. J. \& J. P. Smol, 2015. Use of algae in ecological assessments. In Wehr, J. D., R. G. Sheath \& J. P. Kociolek (eds), Freshwater Algae of North America. Academic Press, San Diego: 921-962.

Stevenson, R. J., Y. D. Pan \& H. van Dam, 2010. Assessing environmental conditions in rivers and streams with diatoms. In Smol, J. P. \& E. F. Stoermer (eds), The Diatoms. Applications for the Environmental and Earth Sciences, 2nd ed. Cambridge University Press, Cambridge: 57-85.

Taylor, J. K., 1987. Quality assurance of chemical measurements. Lewis Publishers, Chelsea Michigan.

The European Parliament and the Council of the European Union, 2000. Directive 2000/60/EC of the European Parliament and of the Council of 23 October 2000 establishing a framework for Community action in the field of water policy. Official Journal of the European Union L327: 1-73.

The Swedish Board for Accreditation and Conformity Assessment (Swedac), 2011. Styrelsens för ackreditering och teknisk kontroll (Swedac) föreskrifter och allmänna råd (STAFS 2011:33) 
Van der Molen, J. \& P. Verdonschot, 2004. Standardisation of river classifications: Framework method for calibrating different biological survey results against ecological quality classifications to be developed for the Water Framework Directive. Contract No: EVK1-CT 2001-00089. Results of the La Bresse sampling and analysis workshop. Wageningen

Van de Vijver, B. \& H. van Dam, 2010. Analyse van de Naardermeer ringtest resultaten. Diatomededelingen 34: $21-34$.

Vyverman, W., E. Verleyen, K. Sabbe, K. Vanhoutte, M. Sterken, D. A. Hodgson, D. G. Mann, S. Juggins, B. Van de Vijver, V. Jones, R. Flower, D. Roberts, V. A. Chepurnov, C. Kilroy, P. Vanormelingen \& A. De Wever, 2007. Historical processes constrain patterns in global diatom diversity. Ecology 88: 1924-1931.

Wikipedia, 2015a. Wikipedia:WikiProject. Wikipedia, the free encyclopedia. http://en.wikipedia.org/wiki/Wikipedia:WikiProject. Accessed 02 Mar 2015.

Wikipedia, 2015b. Diatom. Wikipedia, the free encyclopedia. https://en.wikipedia.org/wiki/Diatom. Accessed 02 Mar 2015.

Wikipedia, 2015c. Wikipedia:WikiProject Algae. Wikipedia, the free encyclopedia. https://en.wikipedia.org/wiki/Wikipedia:WikiProject_Algae. Accessed 02 Mar 2015.

Wikipedia, 2015d. Wikipedia:WikiProject Tree of Life. Wikipedia, the free encyclopedia. https://en.wikipedia.org/wiki/Wikipedia:WikiProject_Tree_of_Life. Accessed 02 Mar 2015. 
Wikipedia, 2015e. Wikispecies. Wikipedia, the free encyclopedia. https://en.wikipedia.org/wiki/Wikispecies. Accessed 02 Mar 2015.

Zimmermann, J., N. Abarca, N. Enk, O. Skibbe, W.-H. Kusber \& R. Jahn, 2014. Taxonomic reference libraries for environmental barcoding: a best practice example from diatom research. PLoS One 9: e108793. 


\section{Table 1}

European quality assurance (QA) and quality control measures for diatom counts used in bio-monitoring

\begin{tabular}{|c|c|c|c|c|c|c|c|c|}
\hline Country & Sample origin & No. samples & Diatom analysts & Exercises & Frequency & Organizer & No. of participants & Sampling \\
\hline Austria & $\mathrm{NM}$ & $>200$ & c & $\mathrm{y}$ & Every 3 years & A & $5-6$ & $\mathrm{n}$ \\
\hline Belgium-Flanders & NM, RM & 380 & $A, R, C$ & $n^{b}$ & & $A^{b}$ & & \\
\hline Belgium-Wallonia & $\mathrm{NM}$ & 150 & $A, C$ & $\mathrm{y}$ & Annually & A & & \\
\hline Czech Republic & $\mathrm{NM}$ & $=360$ & $A, R$ & $\mathrm{n}$ & & & & \\
\hline France & NM & $\sim 2000$ & $A, C, R$ & $y^{2}$ & Annually & $A, R$ & $15-25$ & $y$ \\
\hline Germany & NM, RM & $>1000$ & A, C, R & $\mathrm{y}$ & Biannually & $A, R$ & $30-40$ & $\mathrm{n}$ \\
\hline Hungary & NM, RM & $\sim 500$ & $A, R$ & $\mathrm{y}$ & Every 4 years & c & 7 & n \\
\hline Ireland & NM, RM & 250 & A & $=$ & Annually & & & \\
\hline Italy & NM, RM & $>800$ & $A, R$ & $y^{f}$ & Occasionally & A & 32 & $\mathrm{n}$ \\
\hline Netherlands 5 & NM, RM & 900 & $A, C, R$ & $\mathrm{y}$ & Annually $y^{*}$ & A & $5-10$ & n \\
\hline NorBAF & & & & $\mathrm{y}$ & Biannually & $\mathrm{C}, \mathrm{R}$ & $15-20$ & $\mathrm{n}$ \\
\hline Estonia & NM & 100 & $\mathrm{R}$ & NorBAFi & & & & \\
\hline Finland & NM, RM & $>400$ & $\mathrm{C}, \mathrm{R}$ & NorBAF & & & & \\
\hline Sweden & NM, RM & $\sim 200$ & $\mathrm{C}, \mathrm{R}$ & NorBAF & & & & \\
\hline Spain & NM, RM & $>1000$ & $\mathrm{C}, \mathrm{R}$ & $\mathrm{n}$ & & & & \\
\hline Portugal & $\mathrm{RM}$ & $\sim 400^{k}$ & $A, C, R$ & n & & & & \\
\hline UK & NM, RM & $=1000$ & $A, C$ & $\mathrm{y}$ & Annually' & c & $50-60$ & $\mathrm{n}$ \\
\hline
\end{tabular}

\begin{tabular}{|c|c|c|c|c|c|c|c|c|c|}
\hline Country & Slide prep. & Counting & No. of count & Workshop & Cert. & Report & Fee & Thresh. & Auditor \\
\hline Austria & $\mathrm{n}$ & $\mathrm{y}$ & $5-7$ & y & $\mathrm{n}$ & $-=$ & Free & $\mathrm{y}$ & y \\
\hline Belgium-Flanders & & & & & & & & $\mathrm{n}$ & \\
\hline Belgium-Wallonia & & $\mathrm{y}$ & & $\mathrm{y}$ & & & & $\mathrm{y}$ & \\
\hline Czech Republic & & & & & & & & $\mathrm{n}$ & $\mathrm{n}$ \\
\hline France & $\mathrm{y}$ & $\mathrm{y}$ & $1-4$ & $\mathrm{y}$ & $\mathrm{n}$ & $\mathrm{y}$ & Free & y & $\mathrm{y}$ \\
\hline Germany & n & $\mathrm{y}$ & $2-4$ & $\mathrm{y}$ & $\mathrm{y}$ & $y^{i}$ & $300 €$ & y & $\mathrm{y}$ \\
\hline Hungary & $\mathrm{y}$ & $\mathrm{y}$ & 2 & $\mathrm{y}$ & $\mathrm{y}$ & $\mathrm{y}$ & $150 €$ & y & y \\
\hline Ireland & & & & & & & & n & \\
\hline Italy & $\mathrm{n}$ & $\mathrm{y}$ & 1 & $\mathrm{y}$ & y & $\mathrm{y}$ & Free & y & \\
\hline Netherlands 5 & $\mathrm{y}$ & $\mathrm{y}$ & 1 & $\mathrm{n}^{\mathrm{i}}$ & n & $\mathrm{y}$ & $550 €$ & $y$ & $\mathrm{n}$ \\
\hline NorBAF & $\mathrm{y}$ & $\mathrm{y}$ & $2-5$ & $\mathrm{y}$ & $\mathrm{y}$ & $y^{4}$ & $300 €$ & $y$ & $\mathrm{y}$ \\
\hline \multicolumn{10}{|l|}{ Estonia } \\
\hline \multicolumn{10}{|l|}{ Finland } \\
\hline \multicolumn{10}{|l|}{ Sweden } \\
\hline Spain & & & & & & & & $\mathrm{n}$ & \\
\hline Portugal & & & & & & & & $\mathrm{n}$ & \\
\hline UK & $\mathrm{n}$ & $\mathrm{y}$ & 5 & $\mathrm{n}^{\mathrm{m}}$ & $\mathrm{n}$ & $\mathrm{y}$ & $£ 300$ & $y^{n}$ & $y^{\circ}$ \\
\hline
\end{tabular}

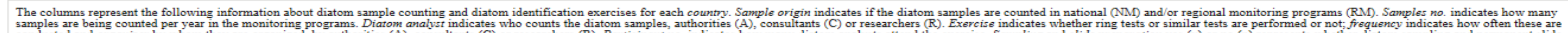

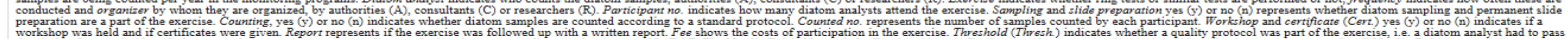

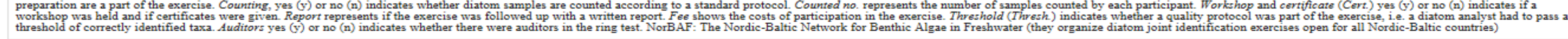
IInternal information, not published

'Flanders Government is planning to organize a ring test in future. Some analysts from Flanders join ring tests in other (neighbouring) countrie:

'Annual ring tests for regional authorities. In a near future, those ring tests will also concern consultants

sSometimes scientific articles

:Analysts from Ireland join the UK/Ireland ring test, and other international exercises

In 2011, a national intercalibration process among agencies through ISS (Superior Institute of Sanity) ISPRA circuit, about the counting and application of the protocol intercalibration common metric index (ICMi) took place

${ }^{3}$ Two different exercises are organized. The official one (RWS Water) is shown in table. The exercises of the NVKD (The Dutch-Flemish Society of Diatomists) are organized more irregularly

"Changed to biannually (2012)

Organized since 2012

jParticipating also in other intermational exercise:

$\mathrm{k}$ This preview was based on the number of available monitoring sites defined during the implementation of the WFD by the nat water Institute

I Five slides per year spread over the year, roughly every 2 months

$\mathrm{m}$ But there is a parallel series of training workshops which often dovetail with the ring tests

$\mathrm{n}$ The ring test is part of a broader accreditation scheme for Agency staff

o A pool of six "experts" and nine "mentors" 